\title{
SART1 wt Allele
}

National Cancer Institute

\section{Source}

National Cancer Institute. SART1 wt Allele. NCI Thesaurus. Code C129082.

Human SART 1 wild-type allele is located in the vicinity of $11 \mathrm{q} 13.1$ and is approximately 18 $\mathrm{kb}$ in length. This allele, which encodes U4/U6.U5 tri-snRNP-associated protein 1, plays a role in mRNA splicing. 